\title{
Evaluation of $\mathrm{NaOH}$ pre-treatment on the corrosion behavior and surface characteristics of hydroxyapatite coated NiTi alloy
}

\author{
G. M. Simsek ${ }^{1} \cdot$ M. Ipekoglu² $\cdot$ G. G. Yapici ${ }^{1}$ (I)
}

Received: 19 June 2020 / Accepted: 23 July 2020 / Published online: 2 August 2020

(c) Springer-Verlag GmbH Germany, part of Springer Nature 2020

\begin{abstract}
Successful short-term implementation of nickel-titanium (NiTi) alloys as implants has been a motivation for the development of long-term applications. However, rendering these as safe implant materials is challenging. The major problem associated with the use of NiTi for in-vivo applications is the potential risk of Ni release from the implant surface due to the corrosive environment of the body. Various methods including surface treatment techniques with acid and alkali solutions and application of biocompatible coatings have been used to overcome these difficulties. In particular, $\mathrm{NaOH}$ pre-treatment has been commonly performed for surface activation of the substrate material to enhance the adhesion properties of coatings. The present work investigates the effect of $\mathrm{NaOH}$ pre-treatment on the hydroxyapatite (HA) coating and the resulting corrosion behavior of and cell response to HA coated NiTi wires. Microstructural examinations showed that the coating integrity deteriorated with prior $\mathrm{NaOH}$ treatment which also increased the corrosion rate as evidenced by potentiodynamic measurements. XPS analysis revealed heightened Ni levels on the sample surfaces and cytotoxicity tests showed decreased cell viability for the samples with pre-treatment. Absence of $\mathrm{NaOH}$ pre-treatment led to lower contact angle values pointing to higher biocompatibility.
\end{abstract}

Keywords NiTi $\cdot$ Coating $\cdot$ Hydroxyapatite $\cdot$ Corrosion $\cdot$ Cell viability $\cdot$ Surface wettability

\section{Introduction}

Nickel-titanium (NiTi) shape memory alloys are increasingly utilized in biomedical fields such as orthopedic [1-3], dental [4] and cardiovascular [5, 6] applications owing to their superior properties including shape memory effect, super-elasticity and reasonable biocompatibility [7]. Having a large force to size ratio and being easily applicable in small dimensions render NiTi wires a favorable material for particular medical applications that require limited operational area and faster implantation. Although NiTi has been utilized very widely in biomedical applications, $\mathrm{Ni}$ release is still arguably the most fundamental concern of using NiTi alloys as an implant material. One promising approach to

G. G. Yapici

guven.yapici@ozyegin.edu.tr

1 Department of Mechanical Engineering, Faculty of Engineering, Ozyegin University, 34794 Istanbul, Turkey

2 Department of Mechanical Engineering, Faculty of Engineering, Turkish-German University, 34820 Istanbul, Turkey inhibit or mitigate Ni leaching is to coat the implant surface with hydroxyapatite (HA) since it shows enhanced corrosion resistance and high resemblance to bone tissue and provides a strong interface [8]. This coating approach aims to obtain a synergistic effect combining extraordinary mechanical and functional properties of NiTi alloys with the biocompatibility of HA to meet the strict requirements for biomedical applications. Among various coating techniques [9-12], dip coating method is a common approach that increases the biocompatibility of the metallic implant by depositing a biocompatible coating layer on the substrate creating an interface between the implant surface and the surrounding tissue $[13,14]$.

In order to improve the stability of the coating layer and to enhance its attachment on the substrate, several researchers have utilized different surface treatment methods on NiTi substrates. With the use of acid and alkali solutions, it is possible to modify the substrate surface for improved coating quality [15]. $\mathrm{NaOH}$ treatment is a well-known method that has been applied to various substrate-coating couples. While there are numerous studies focusing on the positive effects of this treatment on the 
biocompatibility and the following deposition characteristics of the apatite layer [16-20], only a few discussed its disadvantages focusing on NiTi especially on $\mathrm{Ni}$ release after surface treatment using $\mathrm{NaOH}[21,22]$. Hence, combining different strategies as $\mathrm{NaOH}$ pre-treatment and $\mathrm{HA}$ coating to improve the biocompatibility of NiTi samples needs further attention due to the inevitable risk of $\mathrm{Ni}$ release.

Despite the inherent challenges, there have been many efforts reporting that sintering may improve the adhesion by enhancing the bonding at the coating-substrate interface $[23,24]$. Furthermore, sintering may affect the porosity of the coating layer, which is an important property that needs consideration for implantable materials. Sintering treatments typically take place at high temperatures. However, particularly for NiTi alloy, high-temperature sintering may trigger phase transformations and thus results in recrystallization mechanisms which may cause deterioration of the mechanical properties. In this study, thermal treatments were conducted during the sintering step in order to improve the coating adhesion between the HA layer and the underlying NiTi wire substrate surface.

Biocompatibility is one of the crucial features of a successful implantation process. Medical implant materials usually have direct contact with living tissue in a body environment and their response must be tested before the implementation to ensure safe and long-term usage for humans. The in-vitro cytotoxicity test is a widely utilized method which evaluates toxicity and biocompatibility of the implantable materials. Three types of cytotoxicity experiments, extract, direct and indirect contact tests are mainstream for evaluating cytotoxicity [25]. Among these, the indirect cytotoxicity method is commonly applied being highly sensitive, fast and easy to use.

Surface wettability measurements provide the observational basis for a detailed understanding of material surface and behavior in biological environments by evaluating their biocompatibility. In order to analyze surface wettability, contact angle is one of the most convenient and commonly used methods due to its simplicity [26]. Several studies have reported the consistency between wettability values and biocompatibility and proved that biomaterial surfaces with moderate hydrophilicity possess enhanced cell growth and biocompatibility [27, 28].

Studies recorded in the literature evaluating the formation of HA coatings on NiTi utilized substrates in the form of plate $[8,13]$. However, use of wire form metallic implants is inevitable in particular when operational space is limited. NiTi shape memory alloys have been considered efficient implant materials due to their capability of providing high force/mass ratio with small footprint including wire geometry $[29,30]$. Nevertheless, there are few studies focusing on the coating of wire shape substrates [10, 31].
To the best knowledge of the authors, the present study demonstrates for the first time that the effect of surface pre-treatment of wire form NiTi with $\mathrm{NaOH}$ prior to HA coating is noticeable even for low concentrations and adversely affects the corrosion performance and the ensuing biocompatibility. Hence, results of the present study would be instrumental for filling the knowledge gap in HA coating of NiTi wires using the dip coating method and revealing the resultant corrosion performance, surface wettability characteristics and also affirmative behavior in biological environment.

\section{Materials and methods}

\subsection{Sample preparation}

Equiatomic NiTi wire of $0.8 \mathrm{~mm}$ diameter was selected as the substrate. NiTi substrates were treated with $0.5 \mathrm{M}$, $1 \mathrm{M}$ and $4 \mathrm{M} \mathrm{NaOH}$ solutions at $60{ }^{\circ} \mathrm{C}$ for $24 \mathrm{~h}$, followed by drying at $40{ }^{\circ} \mathrm{C}$ for $24 \mathrm{~h}$. Dip coating method was chosen due to favorable outcomes including the provision of a more quantitative coating layer and the non-destructive characteristics and fairly simple procedure of the process. Dip coating suspension was prepared by adding $1 \mathrm{~g}$ of HA (Alfa Aesar, Germany) into $140 \mathrm{ml}$ distilled water followed by vigorous stirring on a magnetic stirrer to obtain a homogenous suspension. NiTi samples were immersed into the dip coating suspension, held for $2 \mathrm{~h}$ and withdrawn with a constant speed of $6 \mathrm{~mm} / \mathrm{s}$ which is followed by heat treatment at $520{ }^{\circ} \mathrm{C}$ for $30 \mathrm{~min}$ in order to accomplish sintering of the HA layer to improve mechanical stability of the coating. Substrates were named according to their $\mathrm{NaOH}$ treatment condition as $\mathrm{XNaOH}-\mathrm{C}$, where $X$ represents the concentration of $\mathrm{NaOH}$ solution and $C$ indicates the application of the subsequent coating process. For instance, $0.5 \mathrm{NaOH}-\mathrm{C}$ refers to the sample which is treated with $0.5 \mathrm{M} \mathrm{NaOH}$ solution followed by $\mathrm{HA}$ coating and heat treatment. Sample naming is summarized in Table 1.

Table 1 Sample naming convention based on $\mathrm{NaOH}$ surface treatment and HA coating conditions

\begin{tabular}{lll}
\hline Sample name & $\begin{array}{l}\text { Concentration of } \mathrm{NaOH} \\
\text { treatment solution }\end{array}$ & $\begin{array}{l}\text { HA coating fol- } \\
\text { lowing NaOH } \\
\text { treatment }\end{array}$ \\
\hline As-received & - & - \\
$\mathrm{C}$ & - & + \\
$0.5 \mathrm{NaOH}-\mathrm{C}$ & $0.5 \mathrm{M}$ & + \\
$1 \mathrm{NaOH}-\mathrm{C}$ & $1.0 \mathrm{M}$ & + \\
$4 \mathrm{NaOH}-\mathrm{C}$ & $4.0 \mathrm{M}$ & + \\
\hline
\end{tabular}




\subsection{Characterization methods}

Following the coating process, the structural integrity of the HA layer was investigated via microstructural observations. Surface morphology of the HA coating layers was studied by scanning electron microscopy (SEM, Zeiss Ultra Plus Field Emission). X-ray photoelectron spectroscopy (XPS, Thermo K-Alpha) measurements were carried out to evaluate the chemical composition of the sample surfaces as a function of $\mathrm{NaOH}$ treatments with varying concentrations. Contact angle measurements were carried out to evaluate the wettability of selected NiTi samples including as-received, $\mathrm{C}, 0.5 \mathrm{NaOH}-$ $\mathrm{C}$ and $1 \mathrm{NaOH}-\mathrm{C}$ samples. All measurements were achieved using a light microscope system. The average contact angles of the selected NiTi surfaces were examined by using the sessile drop technique at room temperature. Experiments were conducted by dropping distilled water onto the surfaces. Average of four consecutive measurements was calculated for each sample.

Corrosion experiments were designed to simulate the body environment and surface treatment conditions are selected to signify the effect of solution concentration. Electrochemical measurements were obtained utilizing a potentiostat (Gamry Interface) to determine the corrosion resistance of the samples in a simulated body fluid (SBF) at $37^{\circ} \mathrm{C}$ with a $\mathrm{pH}$ of 7.4 in order to mimic the body environment.

\subsection{Evaluation of cytotoxicity}

The biological responses of the samples were evaluated via cell culture assessments. In order to determine the cell viability on the NiTi samples, indirect toxicity assessment was conducted using mouse L929 fibroblast cells. As-received, C and $0.5 \mathrm{NaOH}-\mathrm{C}$ samples were evaluated for their cytotoxicity responses. All samples were eluted in a specific cell culture medium involving DMEM $+10 \%$ FBS at $37^{\circ} \mathrm{C}$ for $72 \mathrm{~h}$. A routine subculture was used to maintain the cell line. The samples were placed in a multi well tissue plate and L929 fibroblast cells were seeded with 10.000 of cells $/ \mathrm{ml}$ for each well. The cell attachment process was initiated by keeping all samples in a $\mathrm{CO}_{2}$ incubator at $37{ }^{\circ} \mathrm{C}$ for $24 \mathrm{~h}$. Then, the MTT metabolic activity test was performed and the results were obtained by photometric reading at $570 \mathrm{~nm}$. DMSO solution was used as a positive control while the DMEM medium was used as a negative control. The results were calculated by considering the negative control as $100 \%$ alive.

\section{Results and discussion}

\subsection{Surface morphology}

Surface morphologies of the as-received and coated (with and without $\mathrm{NaOH}$ pre-treatment) samples are shown in Fig. 1a-e. Morphology of the as-received material contains surface irregularities with an initial roughness (Fig. 1a). Formation of a HA layer was observed after dip coating followed by the subsequent heat treatment as evidenced by the disappearance of the grain substructure. The combination of coating and heat treatment resulted in the coalescence of HA particles and the formation of a well-densified layer (Fig. 1b). Previous works report that nanosized HA particles accomplish a dense coating layer even at low sintering temperatures which is in agreement with the observations of the current study [12, 32]. The uniform coating on sample $C$ can be observed in view of the lower magnification SEM micrographs (Fig. 1b-inset) while the other surfaces which belong to $\mathrm{NaOH}$ pre-treated samples have inhomogeneous surface topography pointing to the reduced coating quality with increasing $\mathrm{NaOH}$ concentration. The non-uniform distribution of HA particles is visible as shown in Fig. 1c-e.

\subsection{XPS analysis}

The $\mathrm{Ca} / \mathrm{Ni}$ and $\mathrm{Ni} / \mathrm{Ti}$ coefficients as a function of different surface treatment conditions were obtained using XPS measurements as shown in Fig. 2 to evaluate the effect of $\mathrm{NaOH}$ pre-treatment on the surface characteristics of the samples. Results indicated that the $\mathrm{Ca} / \mathrm{Ni}$ ratio decreased with the increasing concentration of $\mathrm{NaOH}$ treatment denoting elevated Ni levels on the surface of the samples. $\mathrm{The} \mathrm{Ca} / \mathrm{Ni}$ ratio was the most favorable (26.56) for sample $C$ having no surface treatment. Moreover, increasing the concentration of the $\mathrm{NaOH}$ solution intensified the $\mathrm{Ni} / \mathrm{Ti}$ ratio in the treated samples. These findings are in agreement with Chrzanowski et al. [22] reporting increased nickel content in the surface top layer with $\mathrm{NaOH}$ treatment which would pose the potential risk of decreasing the biocompatibility due to the heightened risk of Ni release.

With increasing $\mathrm{NaOH}$ concentration $\mathrm{Ni} / \mathrm{Ti}$ ratio was observed to escalate, indicating that the obtained surfaces are rich in $\mathrm{Ni}$. The increase in the $\mathrm{Ni} / \mathrm{Ti}$ ratio may be attributed to the formation of a thin film in oxide form rich in $\mathrm{Ni}$ on the substrate surface as a result of $\mathrm{NaOH}$ treatment [21]. However, Ni was also traced for the sample without $\mathrm{NaOH}$ treatment although to a much lesser extent as compared to its counterparts with $\mathrm{NaOH}$ treatment. This observation indicates that the increase in $\mathrm{Ni} / \mathrm{Ti}$ ratio may also be related to another phenomenon in addition to the $\mathrm{NaOH}$ treatment. 
Fig. 1 SEM micrographs of NiTi samples with different surface conditions; $\mathbf{a}$ as-received, $\mathbf{b}$ $\mathrm{C}, \mathbf{c} 0.5 \mathrm{NaOH}-\mathrm{C}, \mathbf{d} 1 \mathrm{NaOH}-\mathrm{C}$, e $4 \mathrm{NaOH}-\mathrm{C}$ (a)
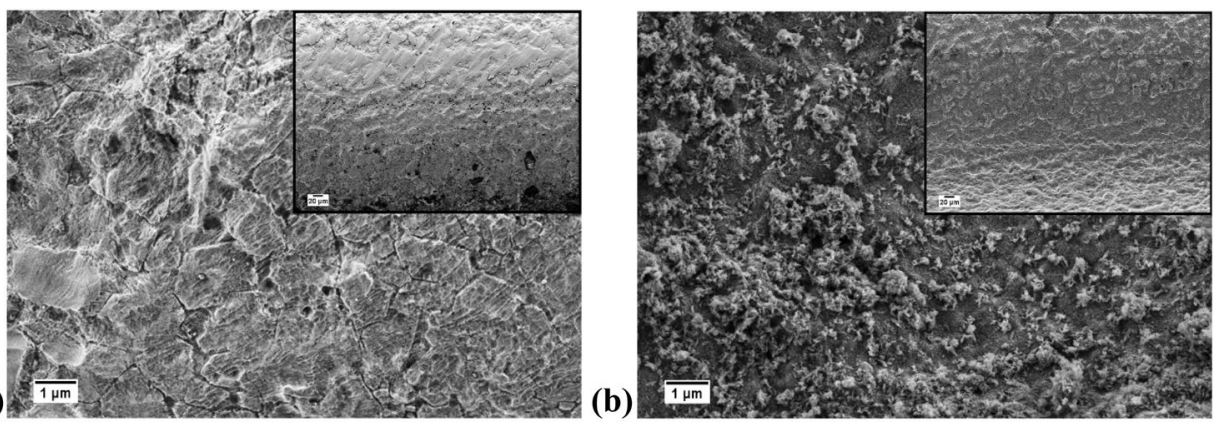

(c)

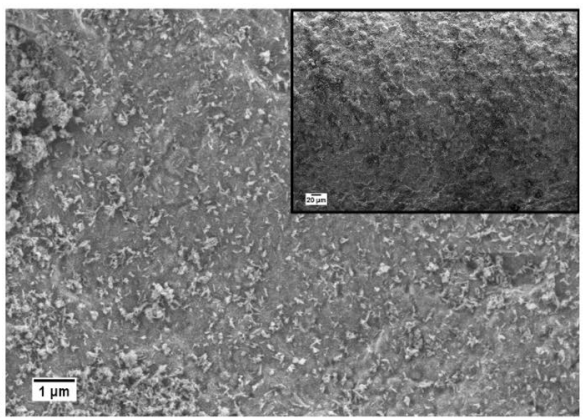

(d)

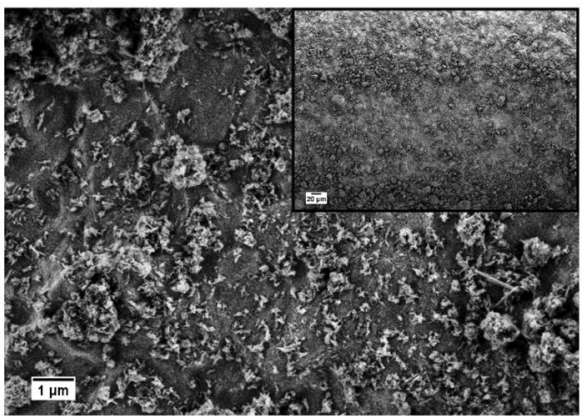

(e)

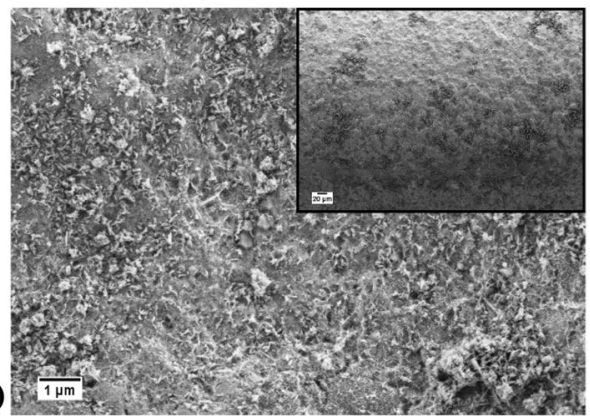

The increase in $\mathrm{Ni} / \mathrm{Ti}$ ratio on the sample surfaces may also be associated with the heat treatment applied for sintering purposes. Several research efforts underline similar observations. For instance, a significant increase of Ni concentration was reported after a heat treatment at $500{ }^{\circ} \mathrm{C}$ for $15 \mathrm{~min}$ [33]. Wu et al. also revealed the effect of heat treatment on the Ni release from NiTi surfaces exhibiting that the released concentration increased significantly between $450{ }^{\circ} \mathrm{C}$ and $550{ }^{\circ} \mathrm{C}$ [34]. However, sintering is a crucial step which may not be omitted in order to obtain a sufficiently strong bond between the HA coating and the NiTi substrate for real life applications. Results obtained in this study indicate that $\mathrm{NaOH}$ treatment and sintering may have a combined effect on the increased $\mathrm{Ni} / \mathrm{Ti}$ ratio however, the former is the dominating factor as observed by the XPS measurements.

Surface irregularities and cracks occurring on the $\mathrm{NaOH}$ treated samples could also affect the $\mathrm{Ni} / \mathrm{Ti}$ ratio. The $4 \mathrm{NaOH}-\mathrm{C}$ has the highest $\mathrm{Ni} / \mathrm{Ti}$ ratio (9.84) and the lowest $\mathrm{Ca} / \mathrm{Ni}$ (1.63) which obviously is not suitable for biomedical applications since a $\mathrm{Ni} / \mathrm{Ti}$ high ratio is undesirable due to the risk of Ni release and its detrimental biological effects [35]. It can be asserted that among the conditions studied, $\mathrm{C}$ displays the most suitable characteristics for biomedical applications by displaying the highest $\mathrm{Ca} / \mathrm{Ni}$ and the lowest $\mathrm{Ni} / \mathrm{Ti}$ ratios.

\subsection{Surface wettability}

Contact angle measurements were conducted to assess the wettability characteristics of selected surfaces (Fig. 3), for which the contact angle values are given in Table 2. As-received NiTi was used as a reference having the highest contact angle. HA coating clearly had a positive effect on decreasing the contact angle thus increasing wettability. However, as it can be seen in Table $2, \mathrm{NaOH}$ treatment resulted in a variation of the contact angle where the contact angle increases as the $\mathrm{NaOH}$ concentration increases. The contact angle values were significantly higher for both $\mathrm{NaOH}$ treated samples when compared with that of the HA coated sample without prior surface treatment. 
Fig. 2 Results of XPS measurements; a curves of selected samples for $\mathrm{Ni}$, Ti and $\mathrm{Ca}$ elements, b $\mathrm{Ca} / \mathrm{Ni}$ and $\mathrm{Ni} / \mathrm{Ti}$ ratios of the samples
$\mathrm{Ni}$

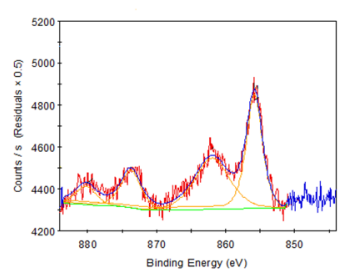

C

$0.5 \mathrm{NaOH}-\mathrm{C}$

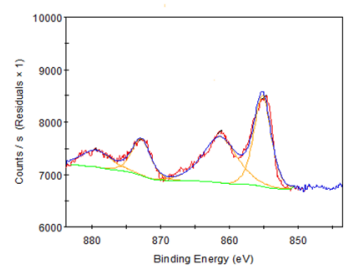

(a)

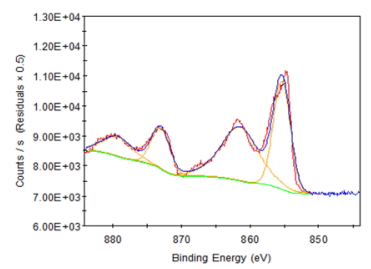

$1 \mathrm{NaOH}-\mathrm{C}$

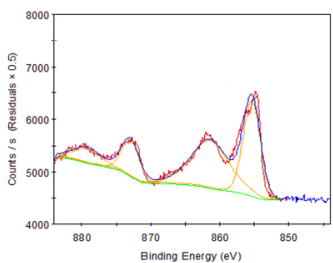

$\mathrm{Ti}$
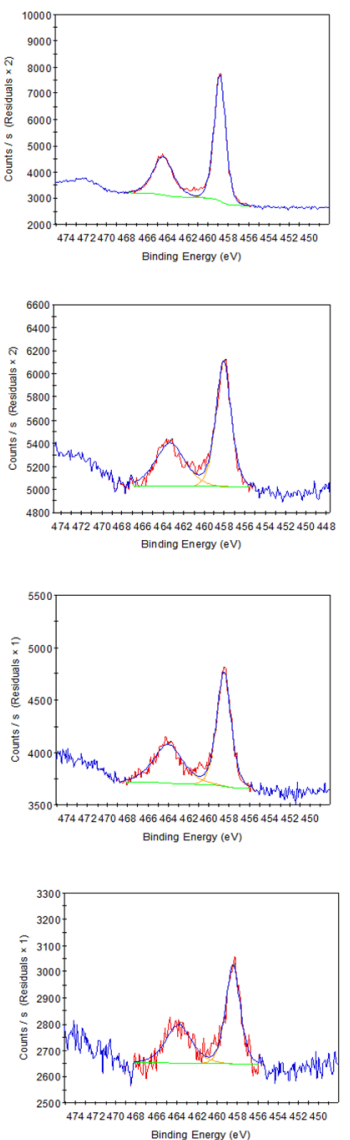

$\mathrm{Ca}$
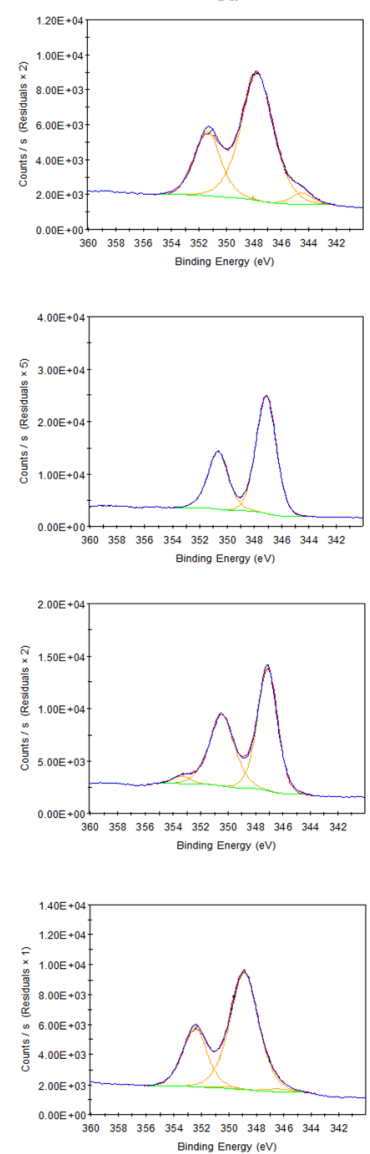

(b)

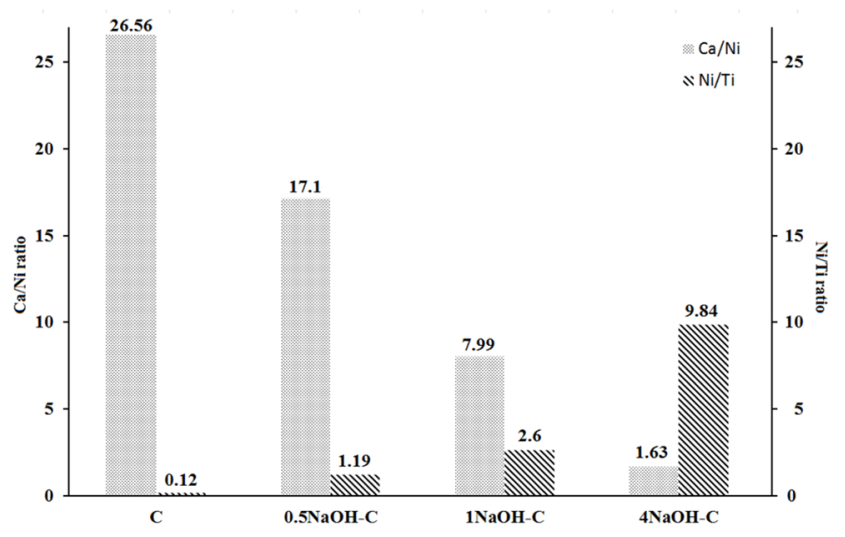

Sample $\mathrm{C}$ has the lowest contact angle value and the surface shows hydrophilic characteristics. Several studies have confirmed that hydrophilic surfaces which have contact angles smaller than $90^{\circ}$ are more suitable for biomedical applications [26]. The low contact angle mostly addresses favorable properties which improve cell attachment onto the surface including good adhesion, high wettability and high surface energy [27]. Results of the contact angle measurements suggest that the surface obtained with HA coating without any prior $\mathrm{NaOH}$ treatment has good adhesion properties and thus might have higher biocompatibility which is clearly evidenced by the findings of cell viability tests as elaborated in the following.

\subsection{Corrosion rate}

Corrosion experiments were performed in SBF solution at $37{ }^{\circ} \mathrm{C}$, according to which the effect of $\mathrm{NaOH}$ treatment on corrosion behavior was found significant. It was determined that sample $\mathrm{C}$ possessed the best corrosion resistance while $4 \mathrm{NaOH}-\mathrm{C}$ has the highest corrosion current density and corrosion rate as given in Table 3. Results of the corrosion 

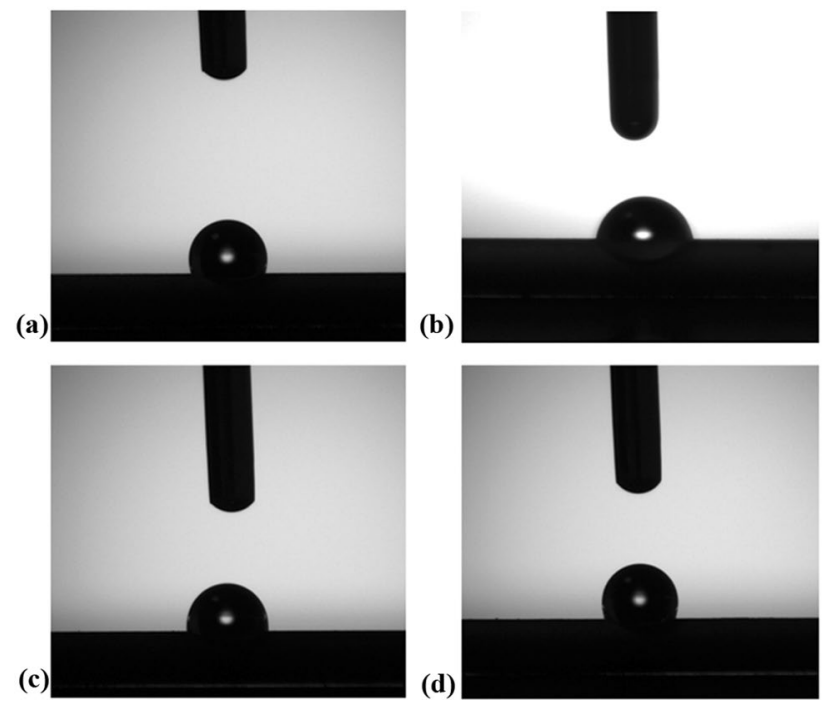

Fig. 3 Images of contact angle measurements; $\mathbf{a}$ as-received, b C, c $0.5 \mathrm{NaOH}-\mathrm{C}, \mathbf{d} 1 \mathrm{NaOH}-\mathrm{C}$

Table 2 Contact angle measurement results for the as-received, $\mathrm{C}$ and $0.5 \mathrm{NaOH}-\mathrm{C}$ conditions

\begin{tabular}{ll}
\hline Sample & $\begin{array}{l}\text { Average } \\
\text { contact angle } \\
\text { (degree) }\end{array}$ \\
\hline As-received & 111.15 \\
$\mathrm{C}$ & 75.81 \\
$0.5 \mathrm{NaOH}-\mathrm{C}$ & 97.83 \\
$1 \mathrm{NaOH}-\mathrm{C}$ & 109.26 \\
\hline
\end{tabular}

Table 3 Potentiodynamic polarization results of samples in simulated body fluid solution

\begin{tabular}{llc}
\hline Sample & $\mathrm{I}_{\text {corr }}\left(\mathrm{A} / \mathrm{cm}^{2}\right)$ & $\begin{array}{c}\text { Corrosion } \\
\text { rate }(\mathrm{mpy})\end{array}$ \\
\hline $\mathrm{C}$ & $3.92 \times 10^{-5}$ & 19.97 \\
$0.5 \mathrm{NaOH}-\mathrm{C}$ & $8.71 \times 10^{-5}$ & 44.33 \\
$1 \mathrm{NaOH}-\mathrm{C}$ & $8.8 \times 10^{-5}$ & 45.04 \\
$4 \mathrm{NaOH}-\mathrm{C}$ & $4.49 \times 10^{-4}$ & 228.90 \\
\hline
\end{tabular}

test denote to pitting corrosion of the $\mathrm{NaOH}$ treated samples where corrosion rates increase with increasing $\mathrm{NaOH}$ concentration. The polarization curves are shown in Fig. 4. The results showed that the corrosion performance degraded with the increased concentration of $\mathrm{NaOH}$ solution.

In Fig. 5, the surface morphology of NiTi samples subjected to SBF solution can be traced. It is notable that the application of $0.5 \mathrm{M} \mathrm{NaOH}$ treatment reveals cracks on the coating layer (Fig. 5b-d) while sample $\mathrm{C}$ has crack-free morphology pointing to a more stable coating structure against corrosion (Fig. $4 \mathrm{a}-\mathrm{c}$ ). The $\mathrm{NaOH}$ treated sample

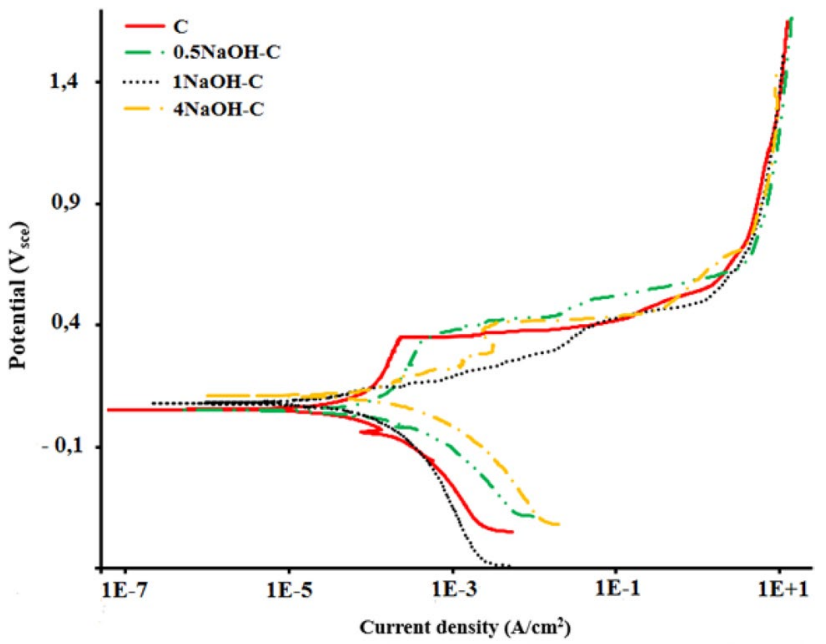

Fig. 4 Polarization curves of NiTi samples with different surface conditions

had a higher pit density on the surface and the surface pits can easily be discerned at high magnification as observed in Fig. 5b. This observation is in parallel with the potentiodynamic polarization test results and may be attributed to the mismatch of the thermal expansion coefficients of the HA coating layer and the underlying oxide layer rich in $\mathrm{Ni}$ which forms due to the $\mathrm{NaOH}$ treatment. Moreover, comparison Fig. $5 \mathrm{c}, \mathrm{d}$ shows that $\mathrm{NaOH}$ treatment leads to a variation in the surface morphology of the samples possibly due to an intermediate oxide layer between the NiTi surface and the HA coating.

\subsection{Cytotoxicity}

Cell culture assessments were obtained using mouse L929 fibroblast cells. After 1-day incubation, the cell viability on the samples was determined via photometric reading. Figure 6 shows that no remarkable toxicity is observed for all samples. The results indicated that L929 fibroblast cells successfully grow on all NiTi surfaces after $24 \mathrm{~h}$ following seeding. As-received sample had relatively lower cell viability compared to the negative. A similar result was obtained for $0.5 \mathrm{NaOH}-\mathrm{C}$ sample which had a lower cell viability compared to the negative and a similar value compared to the as-received sample indicating that the sample with $\mathrm{NaOH}$ pre-treatment followed by HA coating had no significant improvement on the cell viability as compared to the as-received state. On the other hand, sample $\mathrm{C}$ without prior $\mathrm{NaOH}$ treatment had cell viability almost $10 \%$ higher than the sample with $\mathrm{NaOH}$ pretreatment. It can be asserted that this result is promising in favor of the non-treated sample and corroborates the SEM observations (Fig. 1a-c) indicating that the samples 
Fig. 5 SEM micrographs of NiTi samples following corrosion experiments; a sample $\mathrm{C}$ at $\times 100$, b sample $0.5 \mathrm{NaOH}-\mathrm{C}$ at $\times 100$, c sample $C$ at $\times 20 \mathrm{k}, \mathbf{d}$ sample $0.5 \mathrm{NaOH}-\mathrm{C}$ at $\times 20 \mathrm{k}$
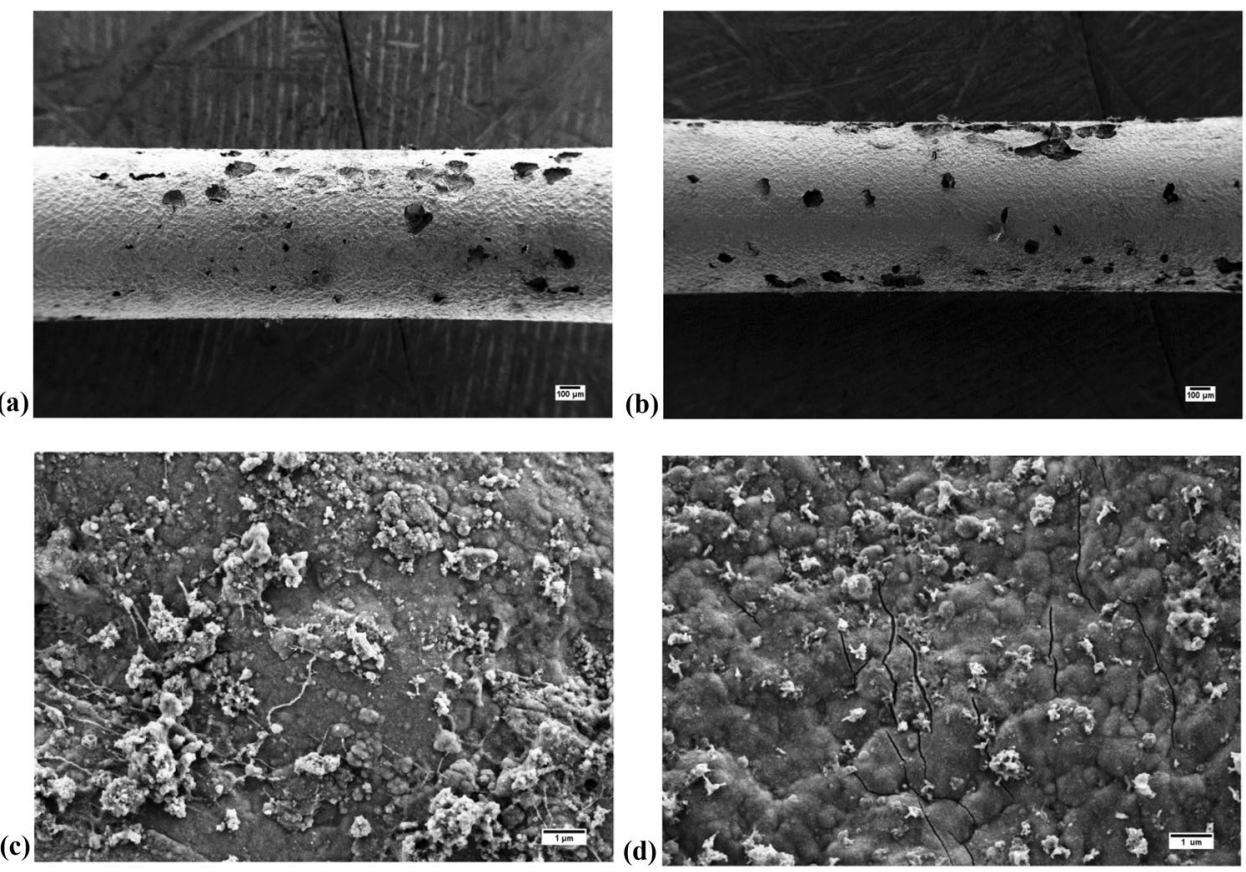

\section{Conclusion}

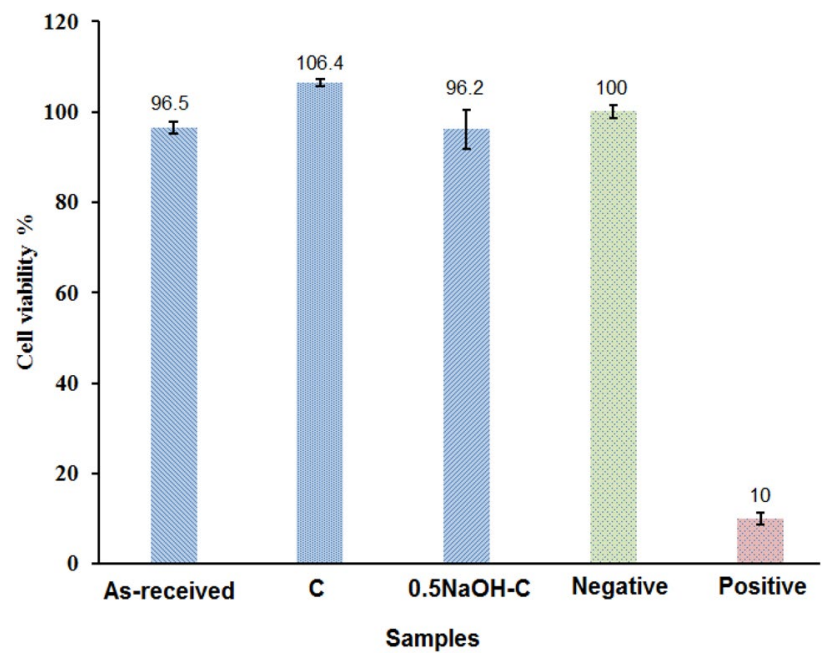

Fig. 6 Cell viability test results of as-received, $\mathrm{C}$ and $0.5 \mathrm{NaOH}-\mathrm{C}$ NiTi samples

without $\mathrm{NaOH}$ treatment result in a more successful subsequent HA coating layer. Accordingly, findings obtained in this work via a blend of surface characterizations and biological analysis have the potential to shed light on the utilization of HA coated NiTi as a prospective implant material. Still, further biocompatibility studies based on the target biomedical application are required for detailed insight regarding the specific use.
$\mathrm{NaOH}$ pre-treatment of substrate materials prior to coating is a widely utilized method to chemically activate the substrate surface in order to achieve better adhesion of coatings. In the present study, the effects of $\mathrm{NaOH}$ treatment on the corrosion resistance of HA coated NiTi shape memory alloys were investigated. HA layers were successfully deposited on untreated and surface treated NiTi via dip coating. It was shown that the application of $\mathrm{NaOH}$ surface treatment strongly and negatively affects coating quality and corrosion resistance. The coated sample without prior surface treatment showed the best corrosion performance. In contrast, elevation in $\mathrm{Ni}$ amount was recorded on the treated sample surfaces with the increase of $\mathrm{NaOH}$ concentration, clearly indicating that coating quality and corrosion resistance deteriorate with $\mathrm{NaOH}$ modification. $\mathrm{NaOH}$ treatment considerably decreased the surface wettability such that the surface without $\mathrm{NaOH}$ treatment prior to HA coating has better wettability characteristics. Cytotoxicity experiments demonstrated the absence of significant toxicity for all samples irrespective of the $\mathrm{NaOH}$ pre-treatment. However, HA coated samples without prior $\mathrm{NaOH}$ treatment resulted in more promising cell viability counts.

Acknowledgements The authors would like to acknowledge Ozyegin University for the financial support throughout this study. 


\section{References}

1. H.F. Li, F.L. Nie, Y.F. Zheng, Y. Cheng, S.C. Wei, R.Z. Valiev, Nanocrystalline Ti49.2Ni50.8 shape memory alloy as orthopaedic implant material with better performance. J. Mater. Sci. Technol. 35, 2156-2162 (2019). https://doi.org/10.1016/j. jmst.2019.04.026

2. C.H. NG, C.W. Chan, H.C. Man, D.G. Waugh, J. Lawrence, NiTi shape memory alloy with enhanced wear performance by laser selective area nitriding for orthopaedic applications. Surf. Coat. Technol. 309, 1015-1022 (2017). https://doi. org/10.1016/j.surfcoat.2016.10.042

3. H. Li, Y. Mao, X. Qu, X. Zhao, K. Dai, Z. Zhu, Nickel-titanium shape-memory sawtooth-arm embracing clamp for complex femoral revision hip arthroplasty. J. Arthroplasty. 31, 850-856 (2016). https://doi.org/10.1016/j.arth.2015.10.044

4. N. Pandis, C.P. Bourauel, Nickel-Titanium (NiTi) Arch Wires: The Clinical Significance of Super Elasticity. Semin. Orthod. 16, 249-257 (2010). https://doi.org/10.1053/j.sodo.2010.06.003

5. D.S. Levi, N. Kusnezov, G.P. Carman, Smart materials applications for pediatric cardiovascular devices. Pediatr. Res. 63, 552558 (2008). https://doi.org/10.1203/PDR.0b013e31816a9d18

6. A.T. Tung, B.H. Park, A. Koolwal, B. Nelson, G. Niemeyer, D. Liang, Design and fabrication of tubular shape memory alloy actuators for active catheters. First. IEEE/RAS-EMBS. Int. Conf. Biomed. Robot. Biomechatron. (2006). https://doi. org/10.1109/BIOROB.2006.1639184

7. K. Otsuka, C.M. Wayman, Shape memory materials (Cambridge University Press, Cambridge, 1999), pp. 27-48

8. X. Wang, F. Liu, Y. Song, Enhanced corrosion resistance and in vitro bioactivity of NiTi alloys modified with hydroxyapatitecontaining A12O3 coatings. Surf. Coat. Technol. 344, 288-294 (2018). https://doi.org/10.1016/j.surfcoat.2018.03.034

9. M. Jamesh, S. Kumar, T.S.N. Sankara Narayanan, Electrodeposition of hydroxyapatite coating on magnesium for biomedical applications. J. Coat. Technol. Res. 9, 495-502 (2012). https:// doi.org/10.1007/s11998-011-9382-6

10. C.F. Dunne, K. Roche, B. Twomey, K.T. Stanton, Deposition of hydroxyapatite onto shape memory NiTi wire. Mater. Lett. 176, 185-188 (2016). https://doi.org/10.1016/j.matlet.2016.04.074

11. Q. Bao, K. Zhao, J. Liu, Characterization of wollastonite coatings prepared by sol-gel on Ti substrate. J. Coat. Technol. Res. 9, 189-193 (2012). https://doi.org/10.1007/s11998-009-9236-7

12. A. Carradò, Nano-crystalline pulsed laser deposition hydroxyapatite thin films on Ti substrate for biomedical application. J. Coat. Technol. Res. 8, 749 (2011). https://doi. org/10.1007/s11998-011-9355-9

13. J. Choi, D. Bogdanski, M. Köller, S.A. Esenwein, D. Müller, G. Muhr, M. Epple, Calcium phosphate coating of nickel-titanium shape-memory alloys. Coating procedure and adherence of leukocytes and platelets. Biomaterials 24, 3689-3696 (2003). https ://doi.org/10.1016/S0142-9612(03)00241-2

14. B. Aksakal, C. Hanyaloglu, Bioceramic dip-coating on Ti-6Al4V and 316L SS implant materials. J. Mater. Sci. Mater Med. 19, 2097-2104 (2008). https://doi.org/10.1007/s10856-007-3304-2

15. X. Liu, P.K. Chu, C. Ding, Surface modification of titanium, titanium alloys, and related materials for biomedical applications. Mater. Sci. Eng. R Reports. 47, 49-121 (2004). https:// doi.org/10.1016/j.mser.2004.11.001

16. W. Qiang, C. Zhen-duo, Y. Xian-jin, S. Jie, Improving the bioactivity of NiTi shape memory alloy by heat and alkali treatment. Appl. Surf. Sci. 255, 462-465 (2008). https://doi.org/10.1016/j. apsusc.2008.06.069

17. H.M. Kim, F. Miyaji, T. Kokubo, T. Nakamura, Effect of heat treatment on apatite-forming ability of Ti metal induced by alkali treatment. J. Mater. Sci. Mater. Med. 8, 341-347 (1997). https://doi.org/10.1023/a:1018524731409

18. P. Li, I. Kangasniemi, K. Groot, T. Kokubo, Bonelike hydroxyapatite induction by a gel-derived titania on a titanium substrate. J. Am. Ceram. Soc. 5, 1307-1312 (1994). https://doi. org/10.1111/j.1151-2916.1994.tb05407.x

19. L. Jonášová, F.A. Müller, A. Helebrant, J. Strnad, P. Greil, Hydroxyapatite formation on alkali-treated titanium with different content of $\mathrm{Na}^{+}$in the surface layer. Biomaterials 23, 3095-3101 (2002). https://doi.org/10.1016/S0142-9612(02)00043-1

20. H. Takadama, H.M. Kim, T. Kokubo, T. Nakamura, TEM-EDX study of mechanism of bonelike apatite formation on bioactive titanium metal in simulated body fluid. J. Biomed. Mater. Res. 57, 441-448 (2001). https://doi.org/10.1002/1097-4636(20011 205)57:3<441:aid-jbm1187>3.0.co;2-b

21. W. Chrzanowski, E.A. Abou-Neel, D.A. Armitage, J.C. Knowles, Surface preparation of bioactive NiTi alloy using alkali, thermaltreatments and spark oxidation. J. Mater. Sci: Mater. Med. 19, 1553-1557 (2008). https://doi.org/10.1007/s10856-008-3374-9

22. W. Chrzanowski, E.A. Abou-Neel, D.A. Armitage, K. Lee, W. Walke, J.C. Knowles, Nanomechanical evaluation of nickeltitanium surface properties after alkali and electrochemical treatments. J. R. Soc. Interface 5, 1009-1022 (2008). https://doi. org/10.1098/rsif.2007.1313

23. M. Wei, A.J. Ruys, B.K. Milthorpe, C.C. Sorrell, J.H. Evans, Electrophoretic deposition of hydroxyapatite coatings on metal substrates: a nanoparticulate dual-coating approach. J. Sol-Gel. Sci. Technol. 21, 39-48 (2001). https://doi.org/10.1023/A:10112 01414651

24. L.A. Sena, M.C. Andrade, A.M. Rossi, G.A. Soares, Hydroxyapatite deposition by electrophoresis on titanium sheets with different surface finishing. J. Biomed. Mater. Res. 60, 1-7 (2002). https:// doi.org/10.1002/jbm.10003

25. International organization for standardization (ISO) 109993 5:2009, Biological evaluation of medical devices - Part 5: tests for in vitro cytotoxicity

26. M. Sandhyarani, T. Prasadrao, N. Rameshbabu, Role of electrolyte composition on structural, morphological and in-vitro biological properties of plasma electrolytic oxidation films formed on zirconium. Appl. Surf. Sci. 317, 198-209 (2014). https://doi. org/10.1016/j.apsusc.2014.08.081

27. Y. Han, D. Chen, J. Sun, Y. Zhang, K. Xu, UV-enhanced bioactivity and cell response of micro-arc oxidized titania coatings. Acta. Biomater. 4, 1518-1529 (2008). https://doi.org/10.1016/j.actbi o.2008.03.005

28. D. Aronov, G. Rosenman, Wettability study of modified silicon dioxide surface using environmental scanning electron microscopy. J. Appl. Phys. 101, 084901-084901 (2007). https://doi. org/10.1063/1.2721945

29. S. Kapila, R. Sachdeva, Mechanical properties and clinical applications of orthodontic wires. Am. J. Orthod. Detofac. Orthop. 96, 100-109 (1989). https://doi.org/10.1016/0889-5406(89)90251-5

30. Z. Laster, A.D. MacBean, P.R. Ayliffe, L.C. Newlands, Fixation of a frontozygomatic fracture with a shape-memory staple. Br. J. Oral Maxillofac. Surg. 39, 324-325 (2001). https://doi. org/10.1054/bjom.2001.0633

31. M.F. Chen, X.J. Yang, R.X. Hu, Z.D. Cui, H.C. Man, Bioactive NiTi shape memory alloy used as bone bonding implants. Mater. Sci. Eng. C. 24, 497-502 (2004). https://doi.org/10.1016/j. msec.2003.11.001

32. T.M. Sridhar, U. Kamachi Mudali, M. Subbaiyan, Sintering atmosphere and temperature effects on hydroxyapatite coated type 316L stainless steel. Corros. Sci. 45, 2337-2359 (2003). https:// doi.org/10.1016/S0010-938X(03)00063-5

33. S.A. Shabalovskaya, J. Anderegg, F. Laab, P.A. Thiel, G. Rondelli, Surface conditions of Nitinol wires, tubing, and as-cast alloys. 
The effect of chemical etching, aging in boiling water, and heat treatment. J. Biomed. Mater. Res. B Appl. Biomater. 65, 193-203 (2003). https://doi.org/10.1002/jbm.b.10001

34. S. Wu, X. Liu, Y.L. Chan et al., Nickel release behavior, cytocompatibility, and superelasticity of oxidized porous single-phase NiTi. J. Biomed. Mater. Res. A. 81, 948-955 (2007). https://doi. org/10.1002/jbm.a.31115

35. H.H. Huang, Y.H. Chiu, T.H. Lee, S.C. Wu, H.W. Yang, K.H. Su, C.C. Hsu, Ion release from NiTi orthodontic wires in artificial saliva with various acidities. Biomaterials 24, 3585-3592 (2003). https://doi.org/10.1016/S0142-9612(03)00188-1

Publisher's Note Springer Nature remains neutral with regard to jurisdictional claims in published maps and institutional affiliations. 